\title{
Corrosion of carbon steel in clay environments relevant to radioactive waste geological disposals, Mont Terri rock laboratory (Switzerland)
}

\author{
Sophia Necib $^{1}$ (1) Nikitas Diomidis $^{2} \cdot$ Peter Keech $^{3} \cdot$ Masashi Nakayama $^{4}$
}

Received: 11 March 2016/Accepted: 22 December 2016/Published online: 21 February 2017

(c) The Author(s) 2017. This article is published with open access at Springerlink.com

\begin{abstract}
Carbon steel is widely considered as a candidate material for the construction of spent fuel and high-level waste disposal canisters. In order to investigate corrosion processes representative of the long term evolution of deep geological repositories, two in situ experiments are being conducted in the Mont-Terri rock laboratory. The iron corrosion (IC) experiment, aims to measure the evolution of the instantaneous corrosion rate of carbon steel in contact with Opalinus Clay as a function of time, by using electrochemical impedance spectroscopy measurements. The Iron Corrosion in Bentonite (IC-A) experiment intends to determine the evolution of the average corrosion rate of carbon steel in contact with bentonite of different densities, by using gravimetric and surface analysis measurements, post exposure. Both experiments investigate the effect of microbial activity on corrosion. In the IC experiment, carbon steel showed a gradual decrease of the corrosion rate over a period of 7 years, which is consistent with the ongoing formation of protective corrosion products. Corrosion product layers composed of magnetite,
\end{abstract}

Editorial handling: P. Bossart and A. G. Milnes.

This paper is \#16 of the Mont Terri Special Issue of the Swiss Journal of Geosciences (see Bossart et al. 2017, Table 3 and Fig. 7).

Sophia Necib

Sophia.necib@andra.fr

1 Andra, Meuse/Haute-Marne-Centre, RD 960, 55500 Bure, France

2 Nagra, Hardstrasse 73, 5430 Wettingen, Switzerland

3 NWMO, 22 St. Clair Avenue East, Toronto, ON M4T2S3, Canada

4 JAEA, Hokushin 432-2, Hokkaido, Horonobe-Cho 098-3224, Japan mackinawite, hydroxychloride and siderite with some traces of oxidising species such as goethite were identified on the steel surface. Microbial investigations revealed thermophilic bacteria (sulphate and thiosulphate reducing bacteria) at the metal surface in low concentrations. In the IC-A experiment, carbon steel samples in direct contact with bentonite exhibited corrosion rates in the range of $2 \mu \mathrm{m} /$ year after 20 months of exposure, in agreement with measurements in absence of microbes. Microstructural and chemical characterisation of the samples identified a complex corrosion product consisting mainly of magnetite. Microbial investigations confirmed the limited viability of microbes in highly compacted bentonite.

Keywords Corrosion layers - Corrosion rate measurements $\cdot$ Microbial activity $\cdot$ Surface microcharacterisations - Opalinus Clay · Bentonite $\cdot$ Nuclear waste disposal

\section{Introduction}

The international Mont Terri Project aims to investigate the properties of the Opalinus Clay formation from hydrogeological, geochemical and geomechanical points of view. The Mont Terri geological profile is given in Fig. 1, (Nussbaum et al. 2017). Since 1996, international research has been ongoing in the Mont Terri rock laboratory, involving fifteen organisations who consider clay formations as potential host rocks for deep geological disposal of radioactive waste.

Carbon steel (C-steel) alloys are candidate disposal canister materials in many radioactive waste disposal programmes due to their high structural strength and low and predictable corrosion rate, (Andra 2005; Féron et al. 2008; Patel et al. 2012). After sealing of the repository, the 
Alsace Molasse

Reuchette Formation

Courgenay Formation

Vellerat Formation

St-Ursanne Formation

Baerschwil Formation

Ifenthal Formation

Hauptrogenstein

Passwang Formation

Opalinus Clay

Staffelegg Formation

Klettgau Formation

Bänkerjoch Formation

Schinznach Formation

Zeglingen Formation

Kaiseraugst Formation

Permo-Carboniferous sediments ?

Basement undifferentiated

\section{NNW}

SSE

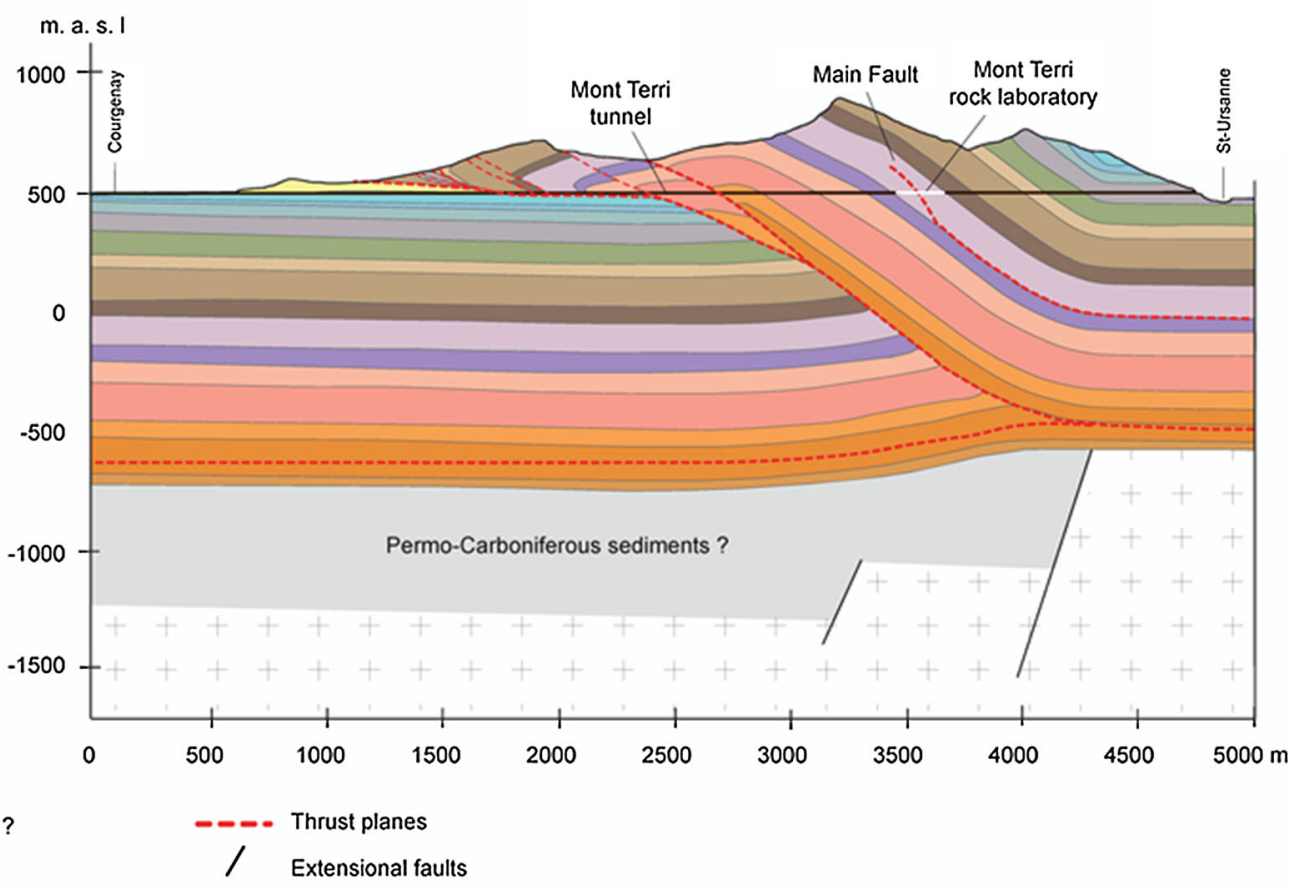

Fig. 1 Geological cross-section of the Mont Terri anticline and location of the Mont Terri rock laboratory

temperature, relative humidity and oxygen concentration at the surface of a disposal canister will vary greatly from the time of emplacement until the end of its lifetime. Upon initial emplacement, the conditions at the canister surface are characterised by high temperatures and readily available oxygen. Gradually, ingress of pore-water from the host rock will induce an increase of relative humidity close to the canister forming an adsorbed water film on the metal surface which is able to sustain electrochemical reactions. In aerated groundwater conditions steel corrosion is generally characterised by the production of a complex mixture of different crystalline and amorphous phases of the oxides and hydroxides of iron. After the consumption of the available oxygen, anoxic conditions will prevail and the canister or casing (for the French concept) will be in direct contact with clay. This final phase dominates the vast majority of the lifetime of the canister.

According to the Pourbaix diagram of $\mathrm{Fe}$ in $\mathrm{Fe}-\mathrm{H}_{2} \mathrm{O}-\mathrm{CO}_{2}$ system, $\mathrm{C}$-steel should be in the corrosion or passive region at neutral and alkaline $\mathrm{pH}$ under anoxic conditions (Chivot 2004). In addition, recent results on the characterisations of archaeological artifacts seem to confirm the long term passive state of C-steel materials in clay soils (Saheb et al. 2013).

In the present paper, the in situ corrosion rate of C-steel materials in clay and bentonite under conditions expected in a deep geological repository has been determined in two distinct experiments. The Iron Corrosion (IC) experiment aims to monitor the instantaneous corrosion rate (CR) of $\mathrm{C}$-steel in contact with Oplinus Clay, by using electrochemical impedance spectroscopy (EIS) measurements. The iron corrosion in bentonite (IC-A) experiment aims to determine the evolution of the average $\mathrm{CR}$ of $\mathrm{C}$-steel in contact with bentonite of different densities by gravimetric and surface analysis measurements. Both experiments aim to gain insight into the relevant corrosion mechanisms by surface analyses and microstructural characterisation of the corrosion products, as well as to define the role of microbes under disposal conditions.

\section{Materials and methods}

\subsection{IC experiment}

\subsubsection{Experimental module set-up and removal}

The test chamber was located in a vertical and descending borehole drilled under nitrogen in Opalinus Clay (Bossart et al. 2017). Due to insufficient air tightness of the packer, the equipment was emplaced about three months after the drilling of the borehole. It contained four $69 \mathrm{~cm}^{2}$ metallic electrodes, electrically insulated from each other with alumina, and mounted on a central tubing (Fig. 2). Two electrodes were made of C-steel (grades E24 and S235) with a ferrite-pearlite microstructure, one electrode was made of Inconel 690 and one electrode was made of 316 stainless steel. The whole setup (about $200 \mathrm{~mm}$ long, $76 \mathrm{~mm}$ diameter) was inserted in a cylindrical Opalinus 


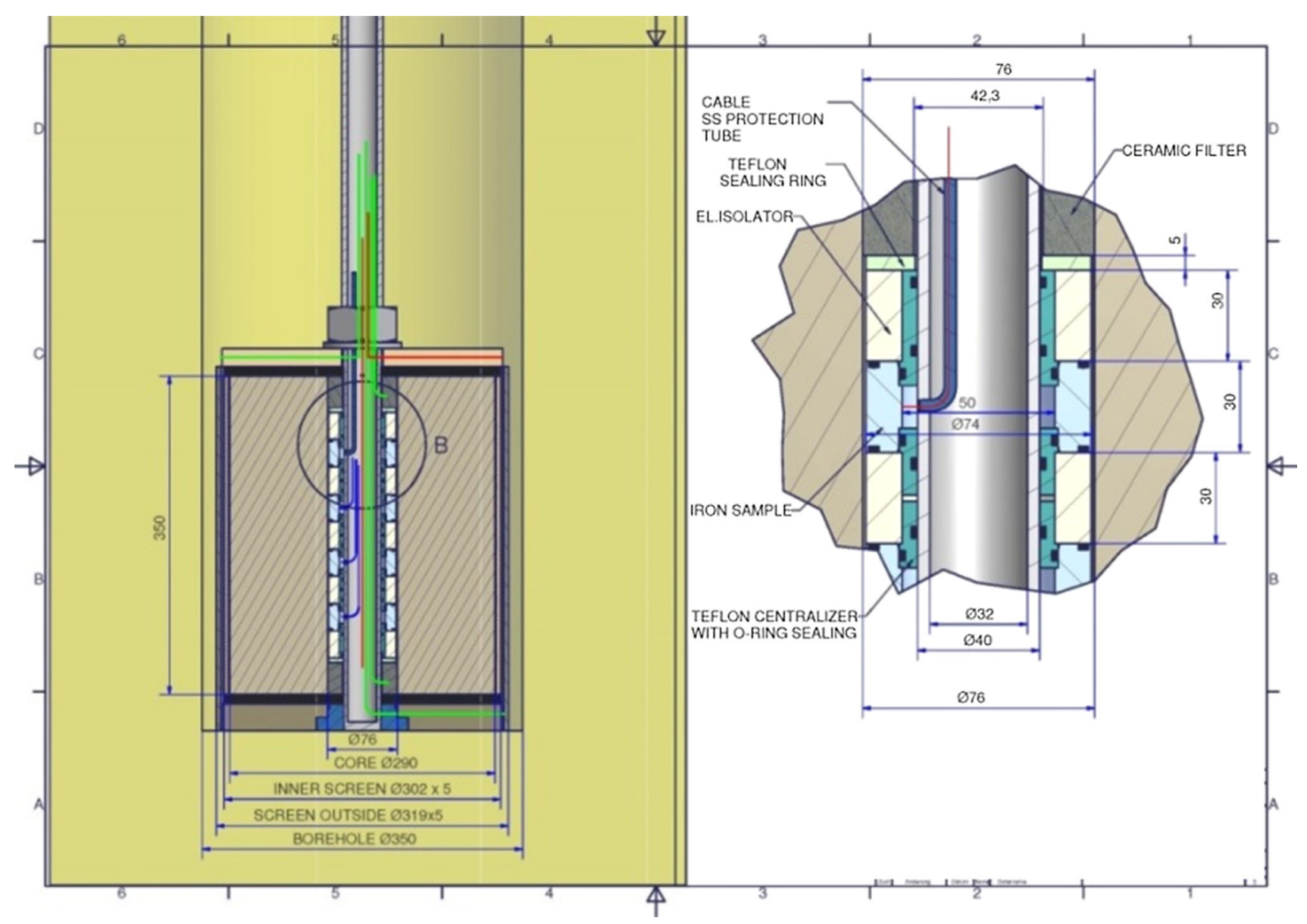

Fig. 2 Experimental set-up showing the test chamber with the metallic electrodes in the IC experiment

Clay borecore (350 $\mathrm{mm}$ long, $290 \mathrm{~mm}$ in diameter) confined in two stainless steel screens, and introduced at the bottom of the borehole at a depth of approximately $8 \mathrm{~m}$. A packer was placed at the top of the test chamber to isolate it from the environment and ensure anoxic conditions. The temperature was initially kept ambient for two years and then increased to $90{ }^{\circ} \mathrm{C}$ using a heating system circulating hot water via the central tubing. The initial space between the metallic electrodes and the Opalinus Clay borecore was limited to $1 \mathrm{~mm}$ void so that corrosion occurred in a relatively confined configuration.

The electrolyte, initially a synthetic solution with a composition representative of Opalinus Clay pore-water (Table 1) (Pearson 2002; Pearson et al. 2003), was injected in the test chamber, which was maintained at the pressure of the environment ( $\sim 14$ bars). The water flow-rate was manually set to ensure circulation between the metallic electrodes and the Opalinus Clay borecore, collect water samples and monitor chemical parameters such as the $\mathrm{pH}$, Eh redox potential and Electric conductivity.

After a total period of 7 years, the equipment was dismantled through a careful extraction of the modules from the borehole. The test chamber was maintained under nitrogen until the cutting operation was performed. It aimed to isolate the different electrodes for further characterisation. The electrode made of C-steel (E24 grade) was cut in two halves; one for microbial analyses (E24-a sample) and the other one for surface micro-characterisations (E24-b sample).

\subsubsection{Corrosion rate measurements}

During the thermal phase, the CR was monitored by performing electrochemical measurements. Two different

Table 1 Composition of the synthetic Opalinus Clay pore-water at $25{ }^{\circ} \mathrm{C}$, initially injected in the IC experiment

\begin{tabular}{llllllllll}
\hline Elements & $\mathrm{Sr}$ & $\mathrm{Na}$ & $\mathrm{Cl}$ & $\mathrm{K}$ & $\mathrm{Mg}$ & $\mathrm{Ca}$ & $\mathrm{HCO}_{3}$ & $\mathrm{SO}_{4}$ & $\mathrm{pH}$ \\
\hline Contents $(\mathrm{mg} / \mathrm{L})$ & 44 & 5530 & 10,200 & 53 & 41 & 780 & 29 & 1350 & 7.6 \\
\hline
\end{tabular}


three electrode cells were used: a working electrode $(\mathrm{C}$ steel (E24 or S235), a counter electrode (Inconel 690) and a pseudo reference electrode (S235 or E24). Each electrode was connected via a $8-\mathrm{m} \mathrm{Cu}$ wire lead. The measurement set up consisted of a potentiostat WMP3 Biologic remotely driven with the EC-lab software. Open circuit potential (OCP) measurements were carried out for $24 \mathrm{~h}$ prior and further to performing EIS measurements, in order to verify the stability of the OCP as well as the possible influence the EIS measurements might have on the metal surface. For EIS measurements, a classic equivalent circuit, containing a transfer resistor parallel to a constant phase element (CPE) equivalent circuit in low frequency range, was used to model the EIS results (Fig. 3) (Jonscher 1991). The corrosion rate was estimated from the transfer resistor by using the Stern-Geary method, (Stern and Geary 1957; Roberge and Sastri 1994; Chen and Jepson 1999).

Equation (1) presents the relationship between the corrosion current density and transfer resistor.

Equation (2) presents the relationship between the CR and corrosion current density.

$J_{\text {corr }}=\frac{B}{R_{t}}$,

where $J_{\text {corr }}\left(\mu \mathrm{A} /\right.$ year), is the corrosion current density, $R_{t}$ $\left(\Omega \mathrm{cm}^{2}\right)$ is the transfer resistor, B is a constant.

$C R=\frac{M_{\mathrm{Fe}}}{\rho_{\mathrm{Fe}}} \frac{J_{\text {corr }}}{n_{a} F}$,

where, $\mathrm{CR}(\mu \mathrm{m} / \mathrm{year})$ is the corrosion rate, $\mathrm{M}_{\mathrm{Fe}}$ $(55.85 \mathrm{~g} / \mathrm{mole})$ is the atomic mass of iron, $\rho_{\mathrm{Fe}}\left(7.9 \mathrm{~g} / \mathrm{cm}^{3}\right)$ is the volumic mass of iron, $\mathrm{n}_{\mathrm{a}}$ is the number of electrons exchanged in the anodic process, $\mathrm{F}$ is the Faraday constant.

EIS spectra were recorded at OCP with a $10 \mathrm{mV}$ amplitude. Frequency ranged from $1 \mathrm{kHz}$ to $10 \mu \mathrm{Hz}$ with 10 frequency values per logarithmic decade. Repeated measurements were done over a period of 5 years.

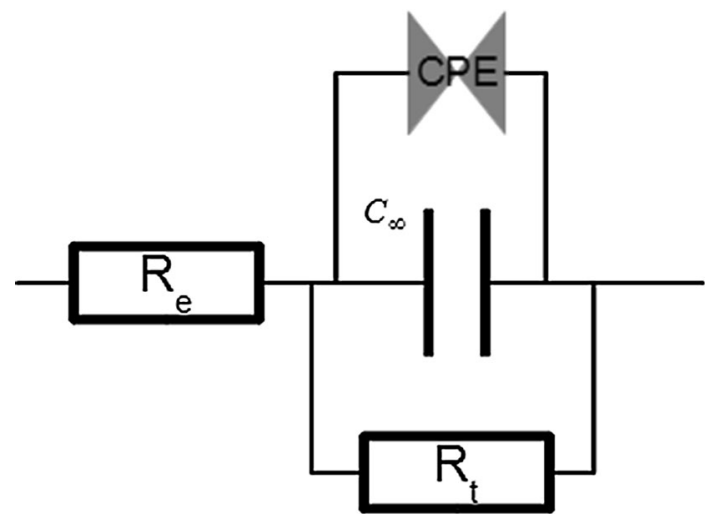

Fig. 3 Equivalent circuit used to calculate the corrosion rate in the IC experiment. $R e$ resistor, $C P E$ constant phase element, $C \infty$ condensator, $R t$ transfer resistor

\subsubsection{Surface characterisations}

The E24-b sample was prepared in a glove box under $\mathrm{N}_{2}$ atmosphere. The electrode surface was first covered with a thin layer of resin (Epofix, Struers) to prevent abrasion during manipulation. A block of $\sim 1 \mathrm{~cm}$ was then recovered by sawing the electrode along two planes parallel to the cylinder axis, using a diamond disk saw (Minitom Struers). This block was then impregnated in resin and polished down to $1 \mu \mathrm{m}$ using silicon carbide papers and eventually diamond pastes. Most polishing was performed dry, with absolute ethanol used only for final polishing and surface rinsing.

Optical images of the metal/Opalinus clay interface were obtained with a Zeiss Imager $\mathrm{M} 2 \mathrm{~m}$ microscope equipped with a CCD camera.

$\mu$-Raman spectra were recorded on a LabRam HR800 microspectrometer with an Olympus BX41 microscope and $50 \times$ long-range objective.

For scanning electron microscopy (SEM), polished cross sections were first coated with a thin carbon layer, then transferred into the microscope. Samples were investigated in Backscattered Electron (BSE) mode using a JEOL JSM7000-F microscope equipped with a field emission gun and operated at $10 \mathrm{kV}$ to improve quantification of oxygen and light elements, and at a current of between 2 and 10 nA. Energy-dispersive X-ray (EDX) spectra were collected using a silicon-drift detector (Bruker XFlash 5010) equipped with a thin beryllium window for the detection and quantification of oxygen. Distribution maps of selected chemical elements were recorded by continuous scanning of the sample and cumulative recording of EDX signal on each pixel.

For micro X-ray diffraction ( $\mu \mathrm{XRD})$, the polished surfaces were glued on glass slides using Canada balsam, then sawed to a thickness of $\sim 1 \mathrm{~mm}$, and polished to obtain a final thickness of about $100 \mu \mathrm{m} . \mu \mathrm{XRD}$ data were recorded in transmission mode. Diffraction patterns were collected with a 2D dimensional detector (GE Healthcare image plate) and circularly integrated with the FIT2D software.

\subsubsection{Microbial activity investigation}

Molecular studies involving PCR-DGGE (polymerase chain reaction-denaturing gradient gel electrophoresis) and PCR SSCP (polymerase chain reaction-single-strand conformation polymorphism) were conducted on water samples from different locations (test chamber and reservoir) and swabs from C-steel surface.

The PCR technique hinges on obtaining enough DNA to make it amplifiable. Two extraction techniques were employed: 
- DNA extraction in DNA-rich or DNA-poor samples using commercial PCR kits (a kit for extraction followed by SSCP and a kit for extraction followed by DGGE).

- DNA extraction in DNA-poor samples using phenolchloroform extraction.

Water samples from the test chamber and the reservoir were taken from the water unit in sterile cells. In addition, swabbing was performed on C-steel metal surface under controlled atmosphere in the glave box. Both, water samples and swabs were investigated by using the most probable number technique (MPN) aiming at determining the concentration of mesophilic and thermophilic sulfurogen bacteria, known to potentially influence the corrosion processes, (Daumas et al. 1993). The mesophilic and thermophilic bacteria grow preferably at temperatures ranging from 20 to $44^{\circ} \mathrm{C}$ and above $45^{\circ} \mathrm{C}$, respectively.

Counting the sulphate and thiosulphate-reducing bacteria (SRB and ThRB) was carried out by seeding $2 \times 1 \mathrm{~mL}$ of sampled solution on specific anaerobic media (TK Labège BSR and TK Labège BTR), and then diluted several times 10:1 using two flasks per dilution to get the number of bacteria/mL. The positive-testing reactions were seen by the medium turning black after 7 weeks of incubation at $30{ }^{\circ} \mathrm{C}$ (for the mesophilic bacteria) and $60{ }^{\circ} \mathrm{C}$ (for the thermophilic bacteria) due to the reaction of the sulphide produced during bacterial metabolism with the iron present in the medium.

\subsection{IC-A experiment}

\subsubsection{Experimental setup}

The IC-A experiment is conducted within a $15.8 \mathrm{~m}$ long vertical and descending borehole sealed with $2.5 \mathrm{~m}$ long packer system, (Bossart et al. 2017). The test section is $4.2 \mathrm{~m}$ long, between the packer and the bottom of the borehole. The interval is equipped with a slotted stainless steel liner of $6 \mathrm{~mm}$ wall thickness which was set without cementing allowing the ingress of pore-water from the host rock (Fig. 4). Within the test section, 12 stainless steel modules were emplaced initially. The modules have holes and a sintered stainless steel filter to allow for the exchange of pore-water with the host rock. Each module contains compacted bentonite and 12 corrosion coupons (Fig. 5). The corrosion coupons were cut from ASTM A694-08 F65 and ASTM 516 Grade 70 carbon steels both from the base alloy and from a $14 \mathrm{~cm}$ deep electron beam weld and heat affected zone, and had a diameter of $20 \mathrm{~mm}$ and a thickness of $10 \mathrm{~mm}$. Volclay MX-80 bentonite was used for the experiments in four different forms: compacted blocks with a dry density of $1.25 \mathrm{~g} / \mathrm{cm}^{3}$, compacted blocks with a dry density of $1.45 \mathrm{~g} / \mathrm{cm}^{3}$, powder-pellet mixture with a dry density of $1.45 \mathrm{~g} / \mathrm{cm}^{3}$, and compacted blocks with a dry density of $1.55 \mathrm{~g} / \mathrm{cm}^{3}$. The corrosion coupons and bentonite were assembled in the modules as shown in Fig. 5, under anoxic conditions. The modules were then partly presaturated $(\sim 90 \%)$ in anoxic synthetic Opalinus Clay pore-water (Pearson 2002) prior to shipping to the Mont Terri rock laboratory for emplacement.

The time span between drilling of the borehole and emplacement of the 12 test modules was about 10 months. During this period the borehole was kept under anoxic conditions and natural Opalinus Clay pore-water ingressed in the borehole at an average rate of $44 \mathrm{ml} /$ day. During emplacement of the modules an additional $10 \mathrm{~L}$ of synthetic anoxic Opalinus Clay pore-water were added to the borehole in order to ensure that all modules were completely immersed.

About 20 months after emplacement, the first sampling campaign took place. During sampling 3 modules were removed from the borehole. Three new modules were emplaced for the continuation of the experiment which is planned to proceed for a total of 10 years. The removed modules contained the following bentonite forms: powderpellet mixture with a dry density of $1.45 \mathrm{~g} / \mathrm{cm}^{3}$ (Module 1), compacted blocks with a dry density of $1.25 \mathrm{~g} / \mathrm{cm}^{3}$ (Module 2) and compacted blocks with a dry density of $1.55 \mathrm{~g} /$ $\mathrm{cm}^{3}$ (Module 3). Upon removal from the borehole, the modules were emplaced in specially designed stainless steel transfer flasks that were filled with Opalinus Clay pore-water from the borehole and bubbled with argon for 30 min prior to sealing to ensure anoxic conditions during shipping. The transfer flasks were then shipped to the Amec Foster Wheeler laboratories in Harwell, Oxford, UK for dismantling and analyses.

Dismantling of the modules was done in a sterilised argonpurged glovebox. The inner cylindrical filter was cut along its complete length on opposite sides using a hand-held rotating abrasive disc saw. This procedure was carried out in a glovebag to minimise the spread of dust throughout the glovebox. One half of each inner cylindrical filter was removed from the module to expose the inner components of the experiments. Slices of bentonite approximately $1 \mathrm{~cm}$ thick were cut manually across the cylinder of bentonite using a large sharp two-handed knife to provide access to the embedded corrosion specimens. After removal from the bentonite, the corrosion specimens and fragments of bentonite were sealed separately under argon in Mylar bags inside the glovebox to maintain an anoxic environment around the samples. The glovebox was cleaned thoroughly after dismantling each module to minimise cross contamination.

\subsubsection{Corrosion rate measurements}

In order to calculate the corrosion rate of the specimens, two weight loss measurements were carried out 


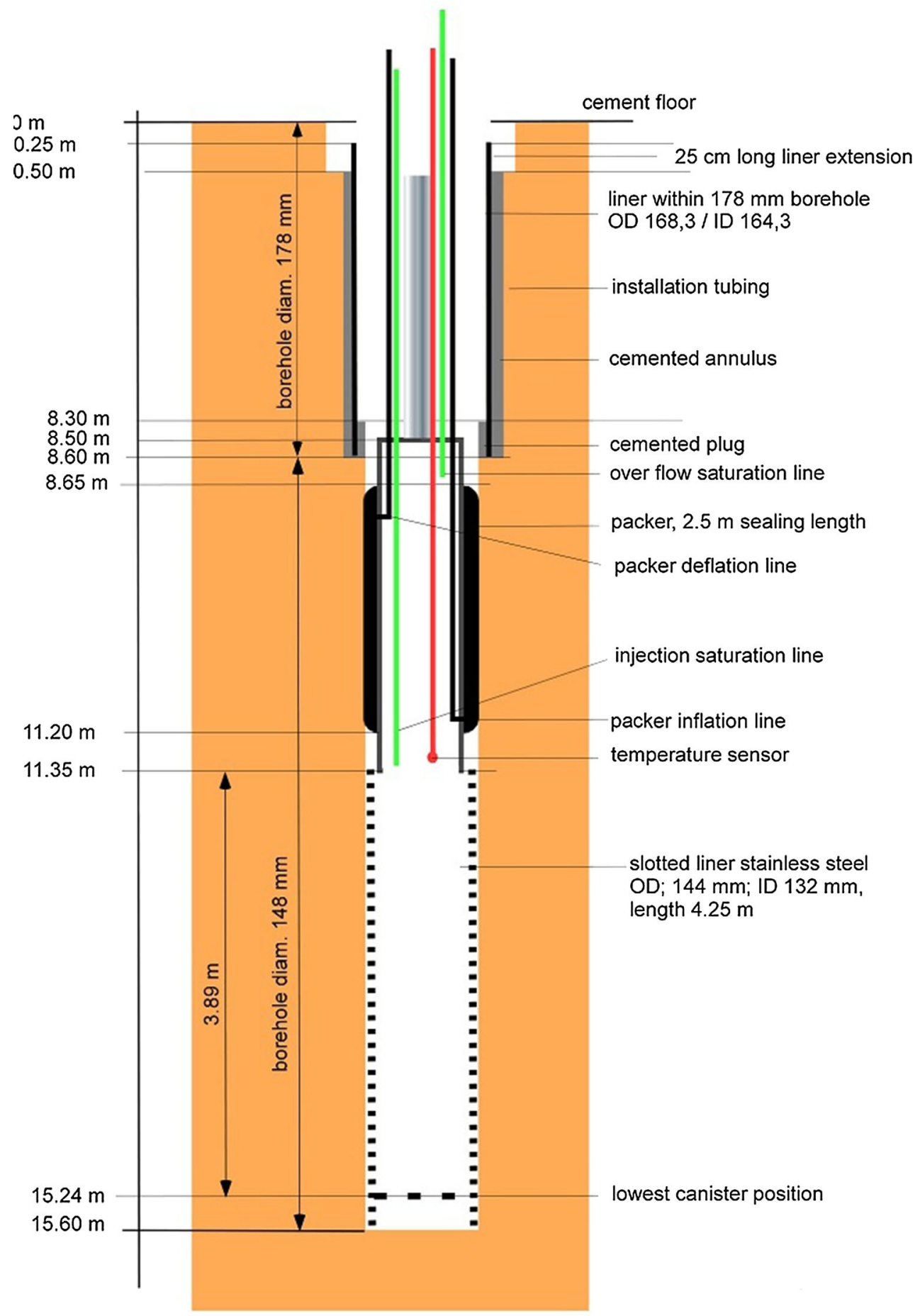

Fig. 4 Borehole layout of the IC-A experiment

on each specimen according to the following procedure. The specimens were cleaned ultrasonically in methanol for $5 \mathrm{~min}$ to remove any residual bentonite. After ultrasonic cleaning, the methanol was decanted and the specimens were left to dry naturally in the glovebox for $10 \mathrm{~min}$. Each specimen was then weighed, following the initial drying stage, to measure the weight after removal of the specimen from the test environment but before any remaining adherent corrosion product scale has been removed. The initial solvent cleaning procedure was followed by descaling the specimens in Clarke's solution (1 litre SG $1.18 \mathrm{HCl}, 50 \mathrm{~g} \mathrm{SnCl}_{2}$, $20 \mathrm{~g} \mathrm{Sb}_{2} \mathrm{O}_{3}$ ) and weighing according to the ASTM G103 standard procedure, (ASTM 2011). The weight loss 


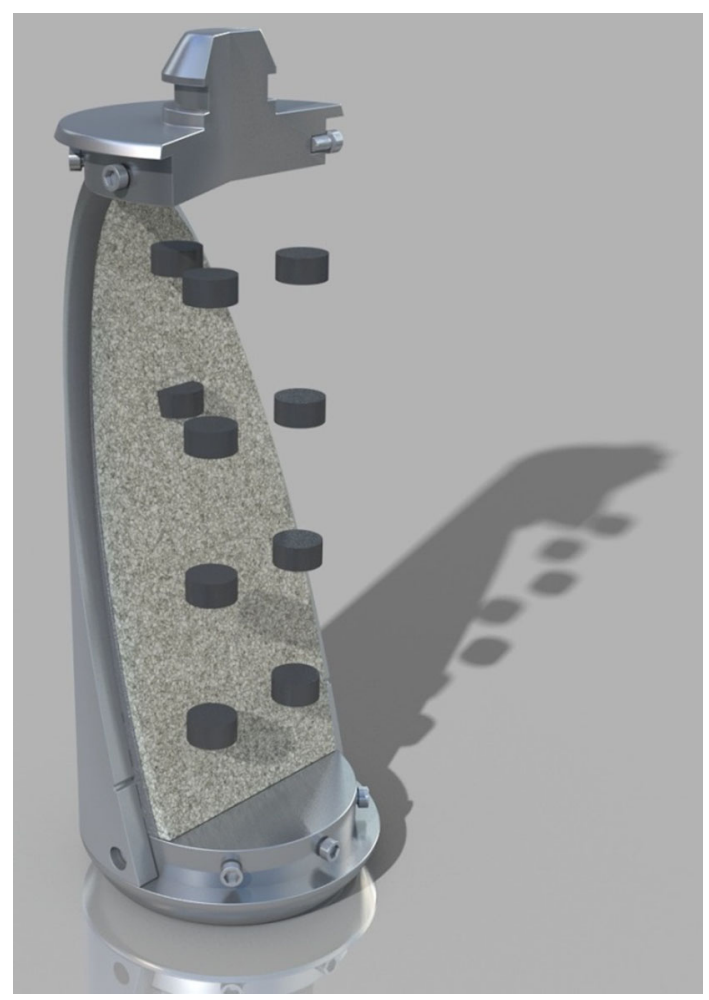

Fig. 5 Illustration of a cutaway of a test module containing bentonite and corrosion coupons in the IC-A experiment

was then converted to a corrosion rate and given in units of $\mu \mathrm{m} /$ year.

\subsubsection{Surface characterisation}

A number of specimens were examined using SEM and EDX analysis. A Hitachi TM3000 SEM equipped with a Bruker X-ray analysis system was used to image the specimens and perform the analysis using EDX.

Raman spectroscopy was used to analyse the corrosion product, using a Horiba JY LabRam Aramis confocal Raman microscope. The exciting laser wavelength used was $532 \mathrm{~nm}$. A $50 \times$ extra-long working distance objective lens was used to collect the $180^{\circ}$ backscattered light. The specimens were loaded into sample holders and held in place using Menzel Gläser cover slips attached to the sample holders using Araldite adhesive.

\subsubsection{Microbial investigation}

The bentonite was cut and sampled with sterile knives and spatulas and packed in sterile sampling bags and then packed in 2 layers of Mylar bags under anoxic conditions and kept at $4{ }^{\circ} \mathrm{C}$. Samples were taken at the edge of the bentonite next to the filter as well as from the center of the module. For the determination of the water content and dry density, the samples were measured, weighed and dried in an oven at $110^{\circ} \mathrm{C}$ until they reached a constant weight. The sample sections for microbiological analyses were cut into smaller pieces under sterile conditions prior to further processing. A suspension was prepared from the small pieces of sample section destined for cell culturing by adding a weighed amount of sample to a known volume of phosphate-buffered saline solution (PBS, i.e., $0.01 \mathrm{M} \mathrm{NaCl}$ buffered to pH 7.6 with $9 \mathrm{mM} \mathrm{Na} \mathrm{NaPO}_{4}$ and $1 \mathrm{mM}$ $\mathrm{NaH}_{2} \mathrm{PO}_{4} \cdot \mathrm{H}_{2} \mathrm{O}$ ), which was then stirred for 30 min to $1 \mathrm{~h}$. Serial dilutions of the suspensions were used in the enumerations. Aerobic heterotrophs were enumerated on R2A medium, Reasoner and Geldreich 1985. Aerobic plates were poured in a laminar flow hood and incubated at $30{ }^{\circ} \mathrm{C}$ for 3-3.5 days. Anaerobic heterotrophs were also cultured on R2A medium in an anaerobic glove box, and incubated at $30{ }^{\circ} \mathrm{C}$ under anaerobic conditions for about 17 to 28 days. Sulphate-reducing bacteria were enumerated by the most-probable number (MPN) method in modified Postgate's B medium, Atlas 1993 and incubated at $30{ }^{\circ} \mathrm{C}$ under anaerobic conditions for 35-71 days.

\section{Results}

\subsection{IC experiment}

The test chamber was initially kept at room temperature for two years and then maintained at $85^{\circ} \mathrm{C}$ until dismantling occurred, i.e. for about 5 years for a total test duration of 7 years. There was a short interruption of the heating phase (two months) at $\mathrm{t}=6.2$ years due to a breakdown of the heating system. The evolution of the temperature at three different locations is presented in Fig. 6. These results emphasise the temperature gradient both, radially and vertically, as well as between the test chamber and the surface water unit. The temperature differences were taken into consideration for the investigations carried out on the different corrosion layers as well as the microbial activity. The physico-chemical parameters such as the Eh redox potential, $\mathrm{pH}$, electric conductivity, etc. were monitored on water via sensors located in the water unit. The Eh redox potential decreased rapidly due to the oxygen consumption by the host rock and corrosion processes, allowing reducing conditions to prevail (Fig. 7). The occasional increases correspond to the electrode calibration and electricity power cuts.

The $\mathrm{pH}$ remained relatively neutral throughout the duration of the experiment (Fig. 8).

From the EIS model of the data, it was evident that the charge transfer resistance increased overtime, and consequently, the CR of both materials, S235 and E24 decreased simultaneously, with initial values around $15 \mu \mathrm{m} /$ year and final values estimated below $1 \mu \mathrm{m} /$ year (Fig. 9). The 


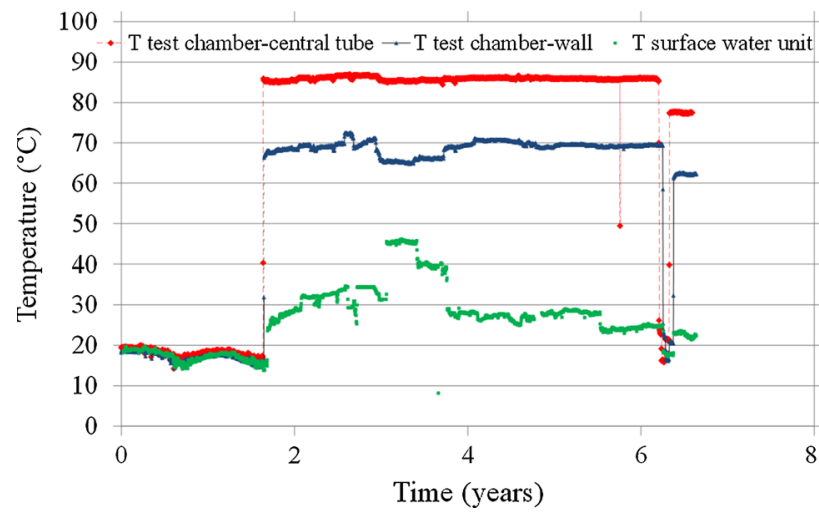

Fig. 6 Temperature evolution at three different locations in the IC experiment: in the test chamber (center and wall) and in the surface water unit

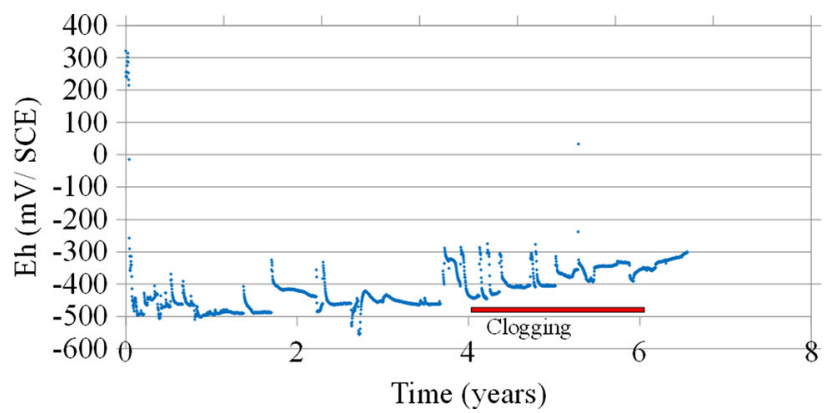

Fig. 7 Evolution of the Eh redox potential measured from the surface water unit in the IC experiment

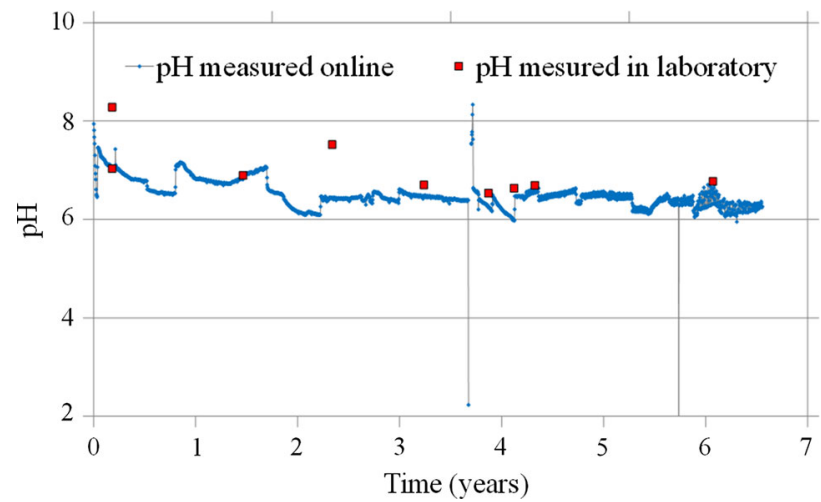

Fig. 8 Evolution of the $\mathrm{pH}$ in the IC experiment

equivalent circuit fitted relatively well the experimental data with a maximum error estimated below $10 \%$. The evolution of the water flow-rate shows variations (Fig. 9).

Despite the manual set, the flow-rate tended to decrease due to the clogging of the water circulation loop. $\mathrm{N}_{2}$ injection was performed when clogging occurred (i.e. at $\mathrm{t}=2.5$ years), which enhanced a congruent increase of the CR (from 4 to 20 and $10 \mu \mathrm{m} /$ year, respectively, for E24 and S235 materials).

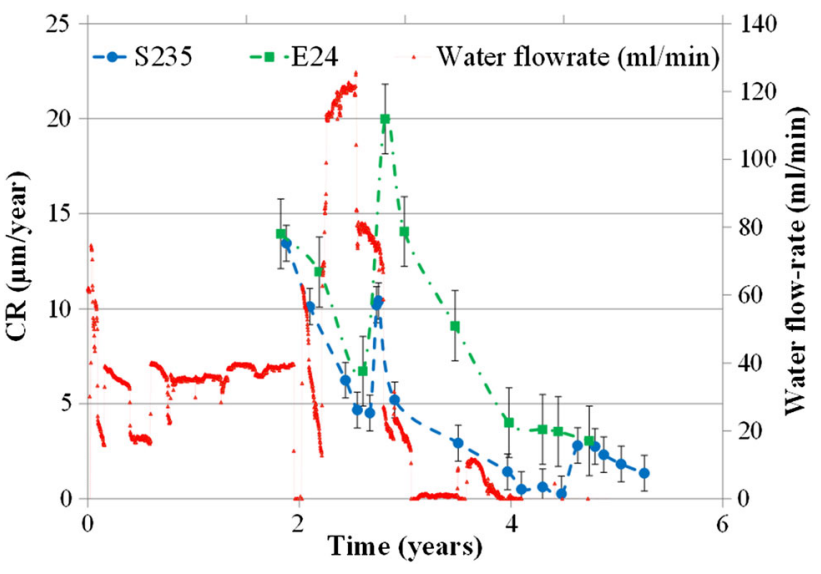

Fig. 9 Evolutions of the CR of C-steel and water flow-rate in the IC experiment: E24 (green squares); S325 (blue circles) and water flowrate (red line)

From $\mathrm{t}=4$ years, the water flow-rate reached $0 \mathrm{ml} / \mathrm{min}$ despite decloggling tentatives. Further tests carried out in the water loops highlighted that the location of the clogging was at the electrodes/Opalinus Clay borecore interface. Consequently, water circulation was hindered and online monitoring of the Eh redox potential, $\mathrm{pH}$ and Electric conductivity was only representative of stagnant water in the water unit.

The characterisation of the E24 metal surface/Opalinus Clay interface revealed mainly non uniform general corrosion with the presence of several layers of corrosion products with distinct compositions identified by EDX analyses, $\mu$-XRD and $\mu$-Raman techniques (Fig. 10). The metal/Opalinus Clay interface highlighted two main regions: the external corrosion products and the internal corrosion products, which are above and underneath the trace of the original surface, respectively. The innermost layers consisted of mixed magnetite $\left(\mathrm{Fe}_{3} \mathrm{O}_{4}\right)$ with two $\mathrm{Cl}-$ containing $\mathrm{Fe}$ compounds, akaganeite and $\beta-\mathrm{Fe}_{2}(\mathrm{OH})_{3} \mathrm{Cl}$. Next, an extended layer of pure chukanovite was determined with a layer mixing $\mathrm{Fe}$ silicate, with nodules of chukanovite, and siderite surrounded by fringes of akaganeite. Porosity is visible by the presence of resin. Close to the trace of the original surface, the corrosion products were essentially made by a layer of siderite, containing discrete, extended domains of goethite, lepidocrocite, Fe sulphide at various oxidation states, or sulphur, together with a thin layer enriched in Fe silicate, and even locally a broad agglomerate of goethite. The trace of the original surface corresponded to a layer enriched in iron sulphide. Finally, outer corrosion products were essentially made by siderite forming a layer close to the trace of the original surface, and occurring as more dispersed material further away in the clay. 

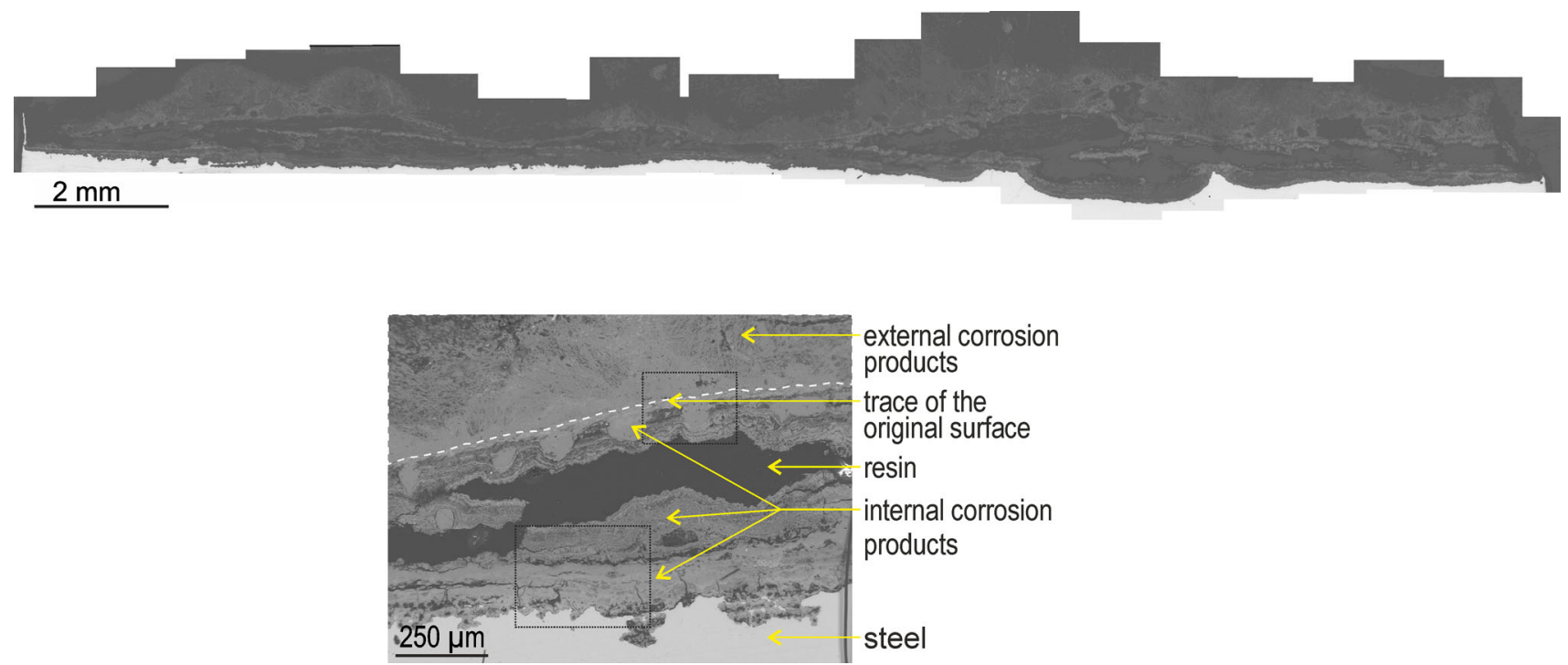

Fig. 10 Characterisations of the E24 metal/Opalinus Clay interface after 7 years in the IC experiment. OM showing the morphology of the interface (top); SEM image (BSE mode) showing the different regions of corrosion products (bottom)

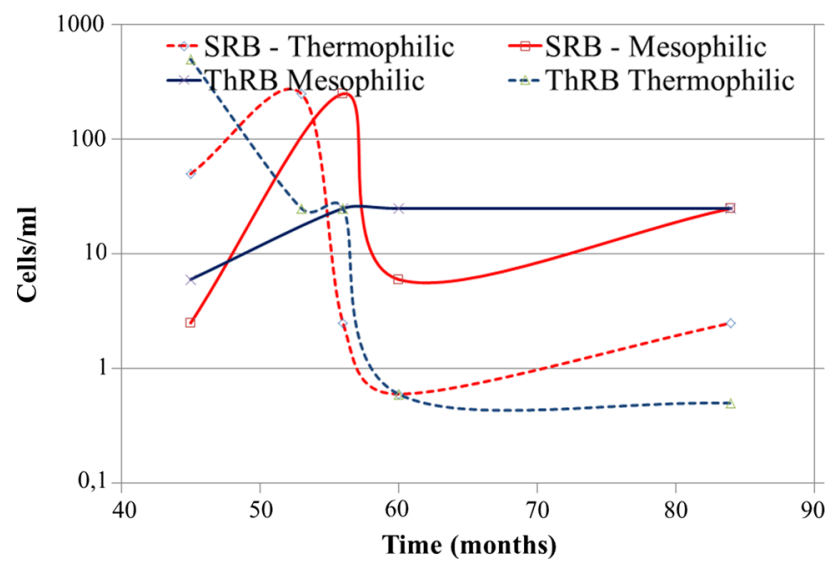

Fig. 11 Evolution of the sulfurogen bacteria (SRB and ThRB) present in pore-water in the IC experiment

Chronologically, chuckanovite likely formed first under deaerated conditions. When anoxic conditions took place, Fe-silicate, chukanovite and magnetite formed as inner corrosion layers and siderite formed as the outer corrosion layer. Chloride species might have formed when the temperature dropped suddenly.

Eventually, a second deaerated step occurred as shown with the formation of goethite.
Biomolecular studies performed on water sampled from the test chamber at $t=5$ years and from the reservoir at $\mathrm{t}=7$ years, revealed the presence of mesophilic and thermophilic bacteria. Moreover, the molecular analyses performed at the $\mathrm{C}$-steel surface showed that bacteria were also present, despite the confined conditions to which the metallic electrodes were exposed.

The results from microbial analyses using the MPN technique, revealed that mesophilic and thermophilic sulfurogen bacteria were present in water sampled from the test chamber throughout the duration of the experiment, at concentrations reaching 150 cells/ml (Fig. 11). After clogging of the water loop, water sampling was performed from the reservoir located on surface and the thermophilic and mesophilic bacteria concentrations decreased to 0.6 and $85 \mathrm{cells} / \mathrm{ml}$ respectively. The microbial analyses conducted on the metal surface essentially revealed thermophilic bacteria, which is consistent with the operating temperature in the test chamber. The measured concentration reached 300 cells $/ \mathrm{cm}^{2}$ (Table 2).

The evolution of the sulphate content shows a first increase compared to the reference value (from 1350 to $3000 \mathrm{mg} / \mathrm{L}$ ) followed by a progressive decrease over three years and a steady state close to the reference value

Table 2 Microbial activity (SRB and ThRB) at the E24 metal surface (swabs) and in Opalinus Clay pore-water taken from the reservoir in surface in the IC experiment

\begin{tabular}{|c|c|c|c|c|}
\hline \multirow{2}{*}{$\frac{\text { Samples }}{\text { Bacteria concentration }}$} & \multicolumn{2}{|l|}{ Swabs (E24-a) } & \multicolumn{2}{|c|}{ Stagnant water (reservoir) } \\
\hline & $30{ }^{\circ} \mathrm{C}$ bacteria $/ \mathrm{cm}^{2}$ & $60{ }^{\circ} \mathrm{C}$ bacteria $/ \mathrm{cm}^{2}$ & $30{ }^{\circ} \mathrm{C}$ bacteria $/ \mathrm{mL}$ & $60^{\circ} \mathrm{C}$ bacteria $/ \mathrm{mL}$ \\
\hline Sulphate-reducing bacteria (SRB) & 33 & $3.310^{2}$ & 25 & 2.5 \\
\hline Thiosulphate-reducing bacteria (ThRB) & 3.3 & 3.3 & 25 & $<0.5$ \\
\hline
\end{tabular}




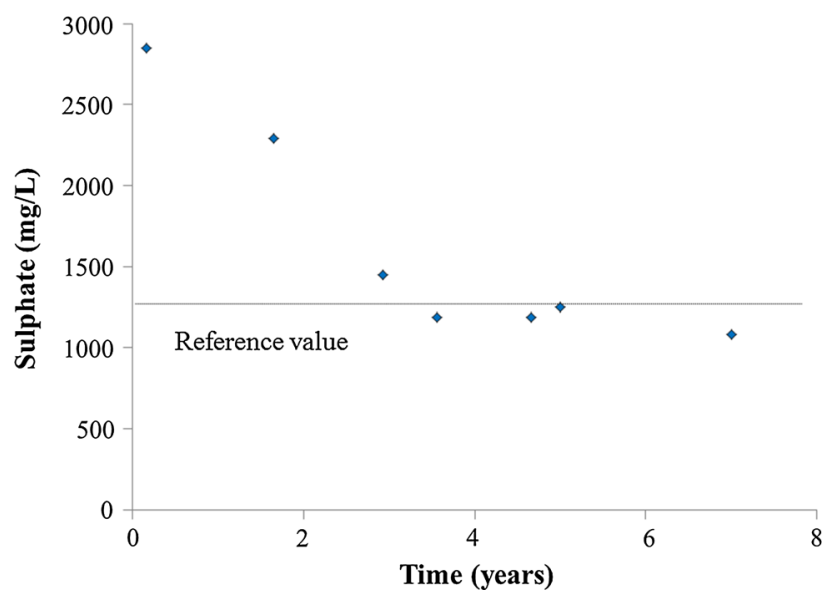

Fig. 12 Evolution of the sulphate content in pore-water in the IC experiment

(Fig. 12). The decrease of the sulphate is congruent with the thermophilic SRB growth (Fig. 11).

\subsection{IC-A experiment}

The average anaerobic corrosion rate of carbon steel in bentonite of different densities measured after 20 months of exposure in natural Opalinus Clay pore-water is shown in Fig. 13. The measured average corrosion rates ranged between 1.5 and $2.25 \mu \mathrm{m} /$ year.

The SEM characterisation of the surface of a representative corrosion coupon, prior to sonication in methanol, is shown in Fig. 14. The SEM images indicate that there are some complex structures on the surface of the specimens

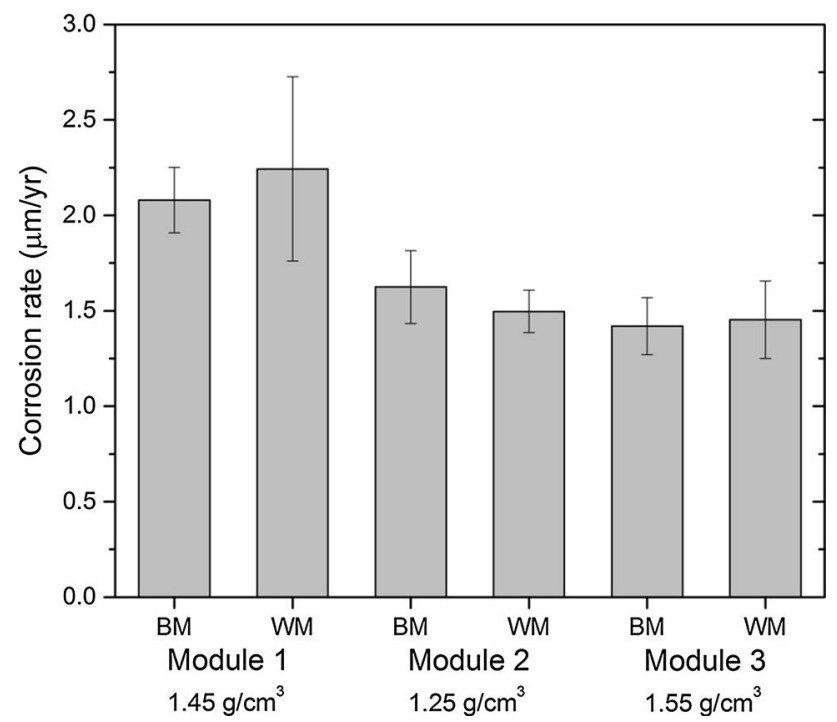

Fig. 13 The average anoxic corrosion rate of carbon steel base metal (BM) and electron beam weld metal (WM) after 20 months of exposure in bentonite of different densities saturated with natural Opalinus Clay pore-water in the IC-A experiment

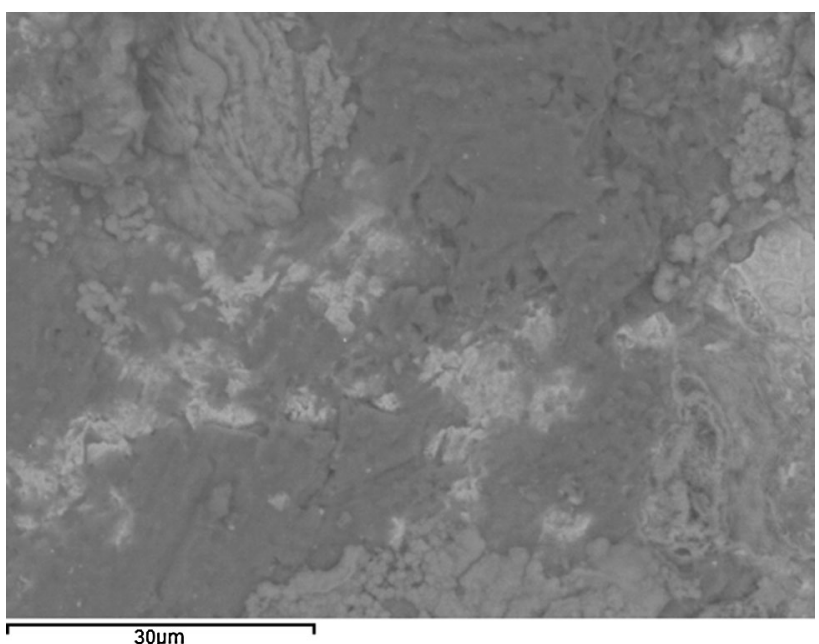

Fig. 14 SEM secondary electron micrograph of the surface of a base metal sample from Module 1 after exposure for 20 months in bentonite saturated with natural anoxic Opalinus Clay pore-water in the IC-A experiment

that vary across the surface of the coupon. EDX plots showed that this complex surface layer consists mainly of $\mathrm{Fe}$ and $\mathrm{O}$, as expected for the corrosion product, while the detection of silicon and aluminium is indicative of the presence of residual bentonite on the coupon surface.

Further chemical characterisation of the corrosion products was done with Raman spectroscopy. The main peak was indicative of magnetite but there was a shift in the position of this peak compared to the standard, which may indicate that the actual corrosion product is sub-stoichiometric or a mixed phase spinel, e.g. $\mathrm{Fe}_{3-x} \mathrm{M}_{x} \mathrm{O}_{4}$. Additional corrosion products consisting of hematite and an oxyhydroxide phase were identified. The composition of the corrosion products was similar to the one identified in previous ex situ studies, (Smart et al. 2016).

Measurements of the dry density of the bentonite exhibited some differences compared to the target values. For Module 1, the dry density values obtained are consistent, yielding an average value of $1.59 \pm 0.07 \mathrm{~g} / \mathrm{cm}^{3}$, which is higher than the targeted density of $1.45 \mathrm{mg} / \mathrm{cm}^{3}$. However, for Module 2, with a targeted density of $1.25 \mathrm{~g} /$ $\mathrm{cm}^{3}$, the average density obtained was $1.53 \pm 0.08 \mathrm{~g} / \mathrm{cm}^{3}$. Finally, for Module 3, the average density is $1.74 \pm 0.05 \mathrm{~g} / \mathrm{cm}^{3}$ for a targeted density of $1.55 \mathrm{~g} / \mathrm{cm}^{3}$. The measured water content followed the reverse trend compared to the measured dry density (Module 1: $32.1 \%$, Module 2: $40.6 \%$, Module 3: 29.3\%). The results indicate that while the measured density decreases in the same order as for the targeted density, the values for the density are significantly higher. Furthermore, there is some variation in the density of bentonite within a single module, suggesting that heterogeneity could be inherent to these systems. 


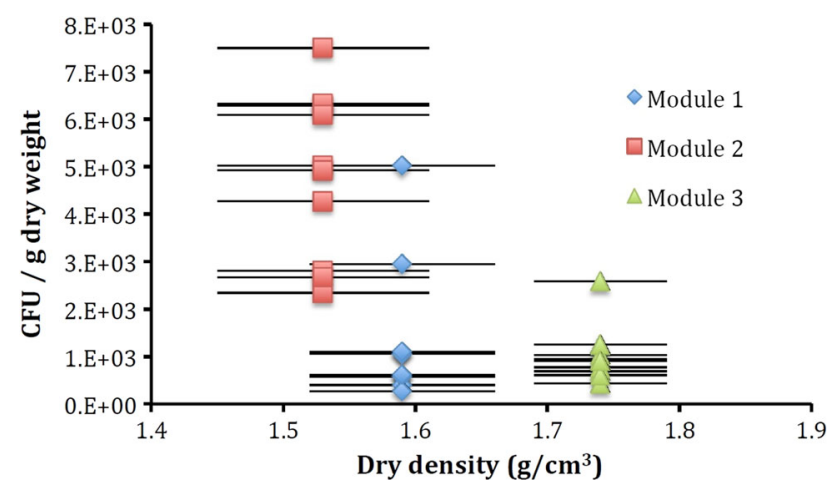

Fig. 15 Summary of cultivation results in the IC-A experiment, for anaerobic heterotrophic microorganisms plotted as a function of measured dry density. $C F U$ colony-forming units

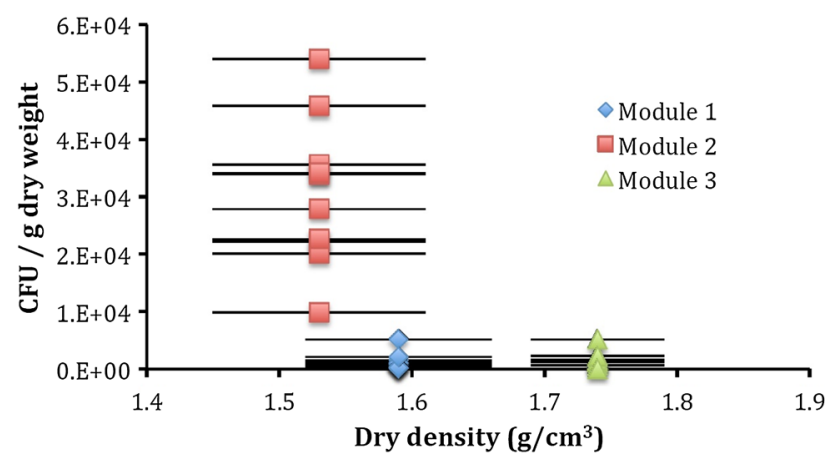

Fig. 16 Summary of cultivation results for aerobic heterotrophic microorganisms in the IC-A experiment, plotted as a function of measured dry density (CFU $=$ colony-forming units)

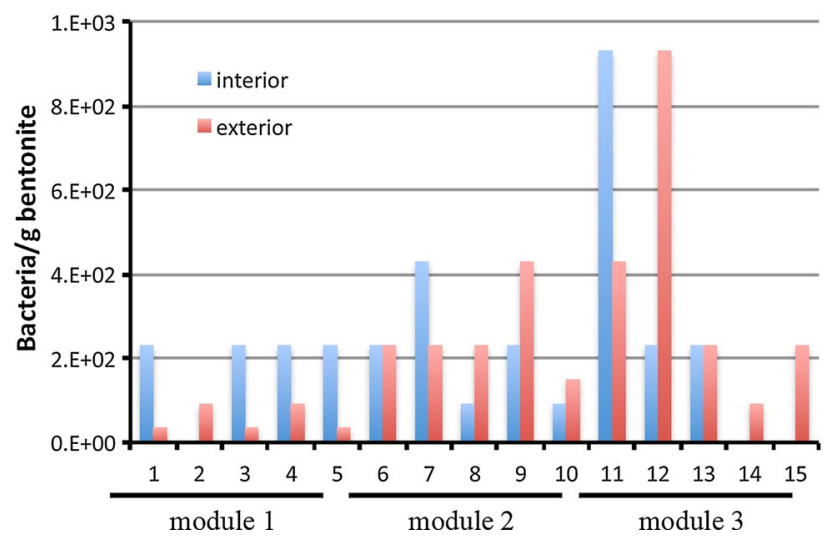

Fig. 17 Summary of cultivation results in the IC-A experiment, for sulphate reducing bacteria in the three modules (Module 1: $1.45 \mathrm{~g} /$ $\mathrm{cm}^{3}$, Module 2: $1.25 \mathrm{~g} / \mathrm{cm}^{3}$, Module 3: $\left.1.55 \mathrm{~g} / \mathrm{cm}^{3}\right)$. The $X$ axis indicates sample numbers

The results of the microbial analyses are shown in Figs. 15, 16 and 17 for anaerobic heterotrophic microorganisms, aerobic heterotrophic microorganisms and sulphate reducing bacteria, respectively. Anaerobic heterotrophic bacteria, i.e. bacteria that use organic compounds as a source of carbon and that grow in the absence of oxygen, were enumerated using anoxic plate cultivation. When comparing the number of anaerobic heterotrophs amongst the three modules, it appears that, as expected, Module 2, with the lowest measured and targeted dry densities, exhibits the highest numbers of anaerobic heterotrophs. Modules 1 and 3, in contrast, both show lower numbers. Aerobic heterotrophic bacteria, using $\mathrm{O}_{2}$ as an electron acceptor, exhibit a similar behavior as the anaerobes, with the difference that cell counts are typically greater for the former. While Module 2 exhibited the largest aerobic heterotroph cell counts, Modules 1 and 3 revealed cell counts within an order of magnitude of each other, but with Module 3 showing the larger counts. Sulphate-reducing bacteria numbers were evaluated by the MPN method showing no clear effect of the bentonite density. The SRB counts were generally higher in the interior than the exterior of each subsample, particularly for Module 1. However, there was no specific trend as a function of location in the subsample for the other two modules.

\section{Discussion}

\subsection{IC experiment}

Initial oxidation likely occurred in the IC-experiment as confirmed by the evolution of the sulphate content which doubled three weeks after the launch of the experiment. This observation is typical when clay rock, containing pyrite, is exposed to air. Indeed, pyrite oxidation enhances the production of hydrogen sulphate released in clay porewater, (Vinsot et al. 2014). The oxidation likely occurred between the drilling phase and installation of the equipment. Despite the oxidation stage, reducing conditions were rapidly set according to the Eh redox potential evolution. In other words, the objectives of the IC experiment to perform long term corrosion experiment could be achieved.

Over a period of about 7 years, the metal surfaces of the E24 and S235 electrodes were in a diffusive regime, at the host rock pressure and rapidly covered by protective layers as demonstrated by the low CR measured overtime. The protectiveness is ensured by "the barrier effect" that the corrosion layers enhance at the metal surface.

Despite mechanical removal of the corrosion layers, which followed the $\mathrm{N}_{2}$ injection, the protectiveness of the metal surface seemed to be maintained thanks to the diffusive regime that was set under limited water circulation first (up to 4 years) and no water circulation (from 4 to 7 years). 
The corrosion layers that formed at the metal surface were characteristic of those found in clay environments, which mainly contained magnetite and siderite. Nevertheless, the presence of oxidized species in significant amounts can be quite surprising. In addition they coexist with important amounts of $\mathrm{Fe}$ (II) (hydroxyl)carbonate phases indicating that the environmental conditions were mainly reducing, and consistent with corrosion rate measurements. The presence of species such as S(-II) seem to rule out simple post-experimental oxidation, and instead confirms that early oxidative events occurred, likely just after the installation of the equipment in the borehole. Late or post-oxidation can not explain the morphology of all of the observed phases.

Overall, the measured bacteria concentrations remained relatively low, likely due to the confined conditions, which limits the ability of the bacteria to grow, spatially. The available nutrients were probably consumed and were not renewed during the experiment because of the clogging, a situation which was not optimal for bacteria growth. Both, thermophilic and mesophilic bacteria were measured, in agreement with the temperature variations of the water circulated in the test chamber. The presence of Fe-sulfide at the metal/Opalinus clay interface could result from sulphate reducing bacteria $(\mathrm{SRB})$ and thiosulphate reducing bacteria (ThRB) metabolism, which can reduce sulphate and thiosulphate into sulphide, (Remazeilles et al. 2010; Ropital 2010). The location of Fe-sulphide close to the trace of the original surface supports the fact that bacteria had initially nutrients and space to grow. In addition, the evolution of sulphate content in pore-water revealed a decrease between $\mathrm{t}=3$ weeks and $\mathrm{t}=3$ years, which was congruent with the thermophilic sulfurogen bacteria growth. However, the most sensible reason to explain the sulphate content decrease is the dilution effect from porewater ingress.

\subsection{IC-A experiment}

The results of the corrosion rate measurements are in good agreement with the anaerobic corrosion rates of carbon steel in bentonite saturated with synthetic pore-waters measured by gas generation, (Smart et al. 2016). In that ex situ experiment, the average corrosion rate of 14 gas cells for a comparable exposure period was $1.9 \mu \mathrm{m} /$ year and the results varied between 1 and $4.5 \mu \mathrm{m} /$ year. This indicates that the presence of natural Opalinus Clay pore-water containing native microbial populations does not have a considerable effect on the corrosion of steel in bentonite. Furthermore, should the observed trend of the ongoing decrease of the corrosion rate persist with time, lower corrosion rates may be expected in future sampling campaigns. For example, in work that is not dissimilar to this study, gas cells measuring corrosion rates under anoxic conditions have undergone exposure durations of 5-10 years and reveal corrosion rates of carbon steel that are currently less than $0.5 \mu \mathrm{m} /$ year, (Smart et al. 2016). In the present experiment the corrosion rates of base metal and electron beam welds did not differ considerably. It is important to mention here that the corrosion rates measured in Module 1 containing bentonite pellets and powder at a density of $1.45 \mathrm{~g} / \mathrm{cm}^{3}$ were higher than those measured in the other two modules that contained bentonite blocks with nominal densities of 1.25 and $1.55 \mathrm{~g} / \mathrm{cm}^{3}$.

With regards to the microbial analyses of aerobic and anaerobic heterotrophic microorganisms, the sampling was carried out in such a way as to allow the evaluation of the impact of location of individual samples on cell counts. There was no clear systematic trend observed from the data, but it appeared that the exterior location typically harbored higher cell numbers than the interior location for plate counts. Furthermore, the variability in the cell numbers of aerobic and anaerobic microorganisms could be explained by the measured heterogeneity of the bentonite density in the modules. With regards to SRB, the fact that there was no clear effect of sampling location on the number of bacteria could be interpreted as SRB originating from the bentonite rather than the pore-water. The SRB numbers were generally higher than those obtained for the Febex experiment, (Stroes-Gascoyne et al. 2013).

The main finding shows that viable microorganisms are present in bentonite and, depending on the density of the clay in the module, a fraction of those microorganisms remain viable, which is in line with previous work by others, (Stroes-Gascoyne et al. 2010). However, as expected at higher densities, a smaller fraction can grow or even survive (i.e. remain viable for post experimental analysis), while at lower densities, a higher fraction survives.

\section{Conclusions}

The anaerobic corrosion of carbon steel has been studied in two in situ experiments at the Mont Terri rock laboratory.

The IC experiment confirmed the feasibility of monitoring in situ the $\mathrm{CR}$ of $\mathrm{C}$-steel in contact with clay in a diffusive regime. The protective nature of the corrosion product layers and the importance of confinement in order to maintain a CR less than $1 \mu \mathrm{m} /$ year have been shown. As expected from the literature, non-uniform general corrosion has been identified and the different corrosion layers as well as their chronological order of formation have been highlighted. Sulfurogen bacteria were identified and were likely responsible for the formation of Fe-sulphide at the $\mathrm{C}$-steel surface. The low CR measured indicate that the 
impact of SRB on the expected lifetime of C-steel disposal canisters is small in a confined diffusive regime.

On the other hand, the on-going IC-A experiment provided insight into the effect of compacted bentonite on the anaerobic corrosion of $\mathrm{C}$-steel. The measured corrosion rates were in agreement with those measured ex situ highlighting the beneficial effect of compacted bentonite in reducing microbially induced corrosion. Furthermore, cell counts indicated that the viability of microbes in bentonite decreases as the dry density increases. The corrosion products after 20 months of exposure mainly consisted of a non-stoichiometric magnetite or mixed phase spinel.

Overall, the corrosion rates of C-steel in contact with clay or bentonite is expected to decrease with time due to the growth of a corrosion product layer under conditions expected in many repository concepts. From a safety assessment point of view, the presented studies have contributed to an increased understanding of corrosion mechanisms and the impact of microorganisms, which can increase the robustness of canister lifetime predictions.

Acknowledgements The authors are grateful to the Mont Terri Consortium for ensuring the success of the IC and IC-A experiments. We thank Paul Bossart, Christophe Nussbaum, Thierry Theurillat, David Jaeggi and Heinz Hauser for their assistance. We would like to thank the experimental partners (Andra, JAEA, Nagra, NWMO) for their financial support. We would also like to thank Solexperts for their significant contributions. S. Necib would like to thank the people who contributed to the IC experiment: Sarah Dewonck from Andra, who initiated the IC experiment; Christian Bataillon for his work on the EIS measurements; Michel Schlegel for his work on the surface characterisation; Sylvie Daumas and Marc Labat for their fruitful work on microbial investigations; Hydroisotop for their remarkable work on the analyses. N. Diomidis would like to thank the people who contributed to the IC-A experiment: Nick Smart, Andy Rance and Bharti Reddy from the Amec Foster Wheeler corrosion team who performed all the analytical work and assembly of the modules; Rizlan Bernier-Latmani, Manon Frutschi and Alexandre Bagnoud from the Environmental Microbiology Laboratoy of the EPFL for their work on microbial investigations. Finally, the authors would like to thank Dr. Fraser King (Integrity Corrosion Consulting Ltd. Nanaimo, BC, Canada) and Dr. Bruno Kursten (Belgian Nuclear Research Centre, Mol, Belgium) for their review and fruitful advice on this work.

Open Access This article is distributed under the terms of the Creative Commons Attribution 4.0 International License (http://crea tivecommons.org/licenses/by/4.0/), which permits unrestricted use, distribution, and reproduction in any medium, provided you give appropriate credit to the original author(s) and the source, provide a link to the Creative Commons license, and indicate if changes were made.

\section{References}

Andra. (2005). Dossier 2005 Argile, Chapitre 4 "Le stockage—Les installations”. pp. 121-136.

ASTM Committee G-1 on Corrosion of Metals. (2011). Standard practice for preparing, cleaning, and evaluating corrosion test specimens. ASTM International.
Atlas, R. M. (1993). Handbook of microbiological media. Boca Raton: CRC Press.

Bossart, P., Bernier, F., Birkholzer, J., Bruggeman, C., Connolly, P., Dewonck, S., Fukaya, M., Herfort, M., Jensen, M., Matray, J-M., Mayor, J. C., Moeri, A., Oyama, T., Schuster, K., Shigeta, N., Vietor, T., \& Wieczorek, K. (2017). Mont Terri rock laboratory, 20 years of research: introduction, site characteristics and overview of experiments. Swiss Journal of Geosciences, 110. doi:10.1007/s00015-016-0236-1 (this issue).

Chen, Y., \& Jepson, W. P. (1999). EIS measurement for corrosion monitoring under multiphase flow conditions. Electrochimica Acta, 44(24), 4453-4464.

Chivot, J. (2004). Thermodynamique des produits de corrosion: Fonctions thermodynamiques, diagrammes de solubilité, diagrammes E-pH des systèmes $\mathrm{Fe}-\mathrm{H} 2 \mathrm{O}, \mathrm{Fe}-\mathrm{CO} 2-\mathrm{H} 2 \mathrm{O}, \mathrm{Fe}-\mathrm{S}-\mathrm{H} 2 \mathrm{O}$, $\mathrm{Cr}-\mathrm{H} 2 \mathrm{O}$ et $\mathrm{Ni}-\mathrm{H} 2 \mathrm{O}$ en fonction de la température. ChatenayMalabry: Andra.

Daumas, S., Magot, M., \& Crolet, J. L. (1993). Measurement of the net production of acidity by a sulphate reducing bacterium: experimental checking of theoretical models of microbially influenced corrosion. Research in Microbiology, 144(4), 237-332.

Féron, D., Crusset, D., \& Gras, J. M. (2008). Corrosion issue in nuclear waste disposal. Journal of Nuclear Materials, 379(1), $16-23$.

Jonscher, A. K. (1991). Low-frequency dispersion in volume and interfacial situations. Journal of Materials Science, 26(6), $1618-1626$.

Nussbaum, C., Kloppenburg, A., Caër, T., \& Bossart, P. (2017). Tectonic evolution around the Mont Terri rock laboratory, northwestern Swiss Jura: constraints from kinematic forward modelling. Swiss Journal of Geosciences, 110. doi:10.1007/ s00015-016-0248-x (this issue).

Patel, R., Punshon, C., Nicholas, J., Bastid, P., Zhou, R., Schneider, C., Bagshaw, N., Howse, D., Hutchinson, E., Asano, R., \& King, F. (2012). Canister Design Concepts for Disposal of Spent Fuel and High Level Waste. Nagra Technical Report, NTB 12-06. Nagra, Wettingen, Switzerland. www.nagra.ch.

Pearson, F. J (2002). PC experiment: Recipe of Artificial pore water. Mont Terri Technical Note, TN 2002-17. Switzerland Federal Office of Topography (swisstopo), Wabern, Switzerland. www. mont-terri.ch.

Pearson, F. J., Acros, D., Bath, A., Boisson, J. Y., Fernandez, A. M., Gabler, H. E., \& Gaucher, E. (2003). Geochemistry of water in the Opalinus Clay formation at the Mont Terri Rock Laboratory. Reports of the Federal Office for Water and Geology (FOWG), Geology Series No 5. Switzerland Federal Office of Topography (swisstopo), Wabern, Switzerland. www.mont-terri.ch.

Reasoner, D. J., \& Geldreich, E. E. (1985). A new medium for the enumeration and subculture of bacteria from potable water. Applied and Environmental Microbiology, 49(1), 1-7.

Remazeilles, C., Saheb, M., Neff, D., Guilminot, E., Tran, K., Bourdoiseau, J.-A., et al. (2010). Microbiologically influenced corrosion of archaeological artefacts: characterization of iron (II) sulfides by Raman spectroscopy. Journal of Raman Spectroscopy, 41(11), 1425-1433.

Roberge, P. R., \& Sastri, V. S. (1994). On-line corrosion monitoring with electrochemical impedance spectroscopy. Corrosion Science, 50(10), 744-754.

Ropital, F. (2010). Corrosion et dégradation des matériaux métalliques: compréhension des phénomènes et applications dans l'industrie pétrolière et des procédés. Paris: Editions TECHNIP.

Saheb, M., Neff, D., Dillmann, P., Descostes, M., \& Matthiesen, H. (2013). Long-term anoxic corrosion of iron. In P. Dillmann, D. Watkinson, E. Angelini, \& A. Adriaens (Eds.), Corrosion and 
conservation of cultural heritage metallic artefacts (pp. 260-284). Woodhead Publishing.

Smart, N. R, Rance, A. P., Reddy, B., \& Diomidis, N. (2016). Anoxic corrosion of carbon steel in bentonite in relation to the swiss deep geological repository concept. In CORROSION 2016. NACE International, Houston, Texas, United States.

Stern, M., \& Geary, A. L. (1957). Electrochemical polarization. a theoretical analysis of the shape of polarization curves. Journal of the Electrochemical Society, 104(1), 56-63.

Stroes-Gascoyne, S., Frutsch, M., Hamon, C., Bagnoud, A., Leupin, O., \& Bernier-Latmani, R. (2013). MA experiment: Role of moisture, bentonite density and water activity on the development of microorganisms in the bentonite after its dismantling from the EB experiment. Mont Terri Technical Report, TR 13-56. Switzerland Federal Office of Topography (swisstopo), Wabern, Switzerland. www.mont-terri.ch.

Stroes-Gascoyne, S., Hamon, C. J., Maak, P., \& Russell, S. (2010). The effects of the physical properties of highly compacted smectitic clay (bentonite) on the culturability of indigenous microorganisms. Applied Clay Science, 47(1), 155-162.

Vinsot, A., Leveau, F., Bouchet, A., \& Arnould, A. (2014). Oxidation front and oxygen transfer in the fractured zone surrounding the Meuse/Haute-Marne URL drifts in the Callovian-Oxfordian argillaceous rock. Geological Society, London, Special Publications, 400(1), 207-220. 